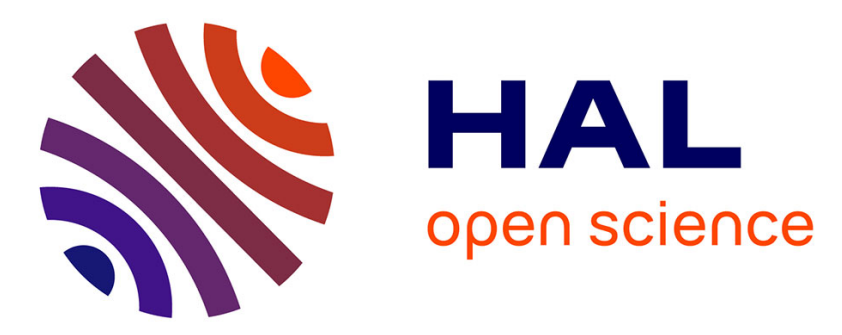

\title{
Durability of concrete exposed to leaching and external sulphate attacks
}

\author{
Emmanuel Rozière, Ahmed Loukili, R. El Hachem, Frédéric Grondin
}

\section{To cite this version:}

Emmanuel Rozière, Ahmed Loukili, R. El Hachem, Frédéric Grondin. Durability of concrete exposed to leaching and external sulphate attacks. Cement and Concrete Research, 2009, 39 (12), pp.11881198. 10.1016/j.cemconres.2009.07.021 . hal-01006757

\section{HAL Id: hal-01006757 https://hal.science/hal-01006757}

Submitted on 8 Dec 2017

HAL is a multi-disciplinary open access archive for the deposit and dissemination of scientific research documents, whether they are published or not. The documents may come from teaching and research institutions in France or abroad, or from public or private research centers.
L'archive ouverte pluridisciplinaire HAL, est destinée au dépôt et à la diffusion de documents scientifiques de niveau recherche, publiés ou non, émanant des établissements d'enseignement et de recherche français ou étrangers, des laboratoires publics ou privés. 


\title{
Durability of concrete exposed to leaching and external sulphate attacks
}

\author{
E. Rozière, A. Loukili *, R. El Hachem, F. Grondin \\ Research Institute of Civil Engineering and Mechanics (GeM), UMR-CNRS 6183, Ecole Centrale de Nantes, France
}

Leaching and external sulphate attack on concrete lead to dissolution of hydration products, mainly portlandite, and in case of ingress of sulphate ions to formation of expansive products such as gypsum and ettringite. Durability of concrete exposed to these environments is still based on prescriptive specifications. The aim of the study is to provide experimental data to design performance based tests and specifications for a comparative approach. Tests have been developed to study these degradations in controlled conditions at constant $\mathrm{pH}$. A leaching test has been performed on concrete. Indicators can be deduced from the leaching test and they are sensitive to the variations of potential durability. An accelerated test using a high sulphate concentration has been performed on mortars. Expansion results are sensitive to mortar mix proportions and the test could be used to qualify cements or binders in a comparative approach. Concrete specimens are exposed to external sulphate attack at two levels of sulphate concentration to provide long-term data that can be used to study the relevance of the accelerated tests and models which are being developed. Results from both series of tests show a correlation between the resistance to leaching and the resistance to external sulphate attack.

\author{
Keywords: \\ C. Durability \\ C. Sulfate attack \\ Leaching \\ D. Sulfate Resistant Cements \\ C. Expansion
}

\section{Introduction}

Leaching is a diffusion-reaction phenomenon which takes place when concrete is exposed to poorly mineralized or acid water. Degradation consists in dissolution of calcium and hydroxide ions out of the matrix, which causes an increase in porosity and transport properties of surface concrete $[1,2]$. Leaching is accelerated in neutral and acid solutions [3,4], and it may be coupled with the ingress of aggressive ions such as chloride, sulphate, magnesium [5]. These issues need to be taken into consideration in the design of concrete structures in contact with ground water-such as nuclear waste containers [6]-and also nuclear cooling towers, wastewater treatment plants and precast concrete products such as water tanks and sewage pipes. The mechanism of degradation of concrete exposed to external sulphate attack depends on exposure conditions, such as temperature $[7,8]$, associated cation $[9,10]$ and sulphate concentration [11-13]. The best known mechanism involves $C_{3} A$ and portlandite in the cement matrix and sulphate ions $[9,14-16]$. The first stage of this mechanism is based on a diffusion-reaction based phenomenon. Sulphate ions react with portlandite to form gypsum, which can in turn react with the hydration products of $C_{3} A$ to form ettringite. The formation of gypsum and ettringite can be expansive. During the second stage of degradation the expansive products that have filled the porosity of concrete cause swelling, damage and finally a strength loss of concrete.

\footnotetext{
* Corresponding author.

E-mail address: ahmed.loukili@ec-nantes.fr (A. Loukili).
}

The everyday durability approach of concrete exposed to leaching and external sulphate attack is prescriptive. Standards [17] are based on limiting values of the maximum water/binder ratio, minimum cement content, minimum compressive strength, and in case of sulphate attack prescriptions on binder are added. In the French standard on concrete NF EN 206-1 [17], the maximum proportion of mineral admixtures such as fly ash and slag is $15 \%$ of the mass of binder, and socalled 'sulphate-resisting' cements are required. Sulphate resistance of cements is defined in other standards $[18,19]$. It generally consists in limiting maximum $\mathrm{C}_{3} \mathrm{~A}$ content ( $5 \%$ in both standards). Such cements are designed either by increasing the $\mathrm{C}_{4} \mathrm{AF} / \mathrm{C}_{3} \mathrm{~A}$ ratio of Portland cements or by increasing the slag proportion in blended slag cements which is contradictory to limits on binder from the standard on concrete.

However cost-effectiveness, environmental and technical issues have shown the need for performance based specifications for the same durability [20]. In existing test procedures resistance of binders to external sulphate attacks is assessed on mortar prisms. Acceleration is obtained by decreasing the volume/exposed surface ratio of specimens and increasing sulphate concentration: $34 \mathrm{~g} / \mathrm{L}$ in ASTM C 1012 [21] and NF P 18-837 [22], $29.8 \mathrm{~g} / \mathrm{L}$ in Wittekindt procedure [23]. But in field exposure conditions sulphate concentration is usually much lower: about $2.7 \mathrm{~g} / \mathrm{L}$ in seawater [24], from 0.2 to $6 \mathrm{~g} / \mathrm{L}$ in groundwater according to the definition of XA exposure classes in European standard EN 206 [17]. Mehta [25] and Brown [26] have shown the influence of $\mathrm{pH}$ on sulphate attack. In a laboratory study, it is typical to use only sodium sulphate, but not magnesium sulphate that would induce a coupled mechanism of degradation involving magnesium ions and $\mathrm{CSH}[9,10]$. 
In this study, the effect of the exposure conditions has been taken into account to develop a representative test on concrete, using automatic control of pH and two levels of sulphate concentration $(3 \mathrm{~g} / \mathrm{L}$ and $30 \mathrm{~g} / \mathrm{L}$ ). Six concrete mixtures have been designed to study the sensitivity of the performance tests. Concrete specimens have been exposed to $\mathrm{pH}$ controlled leaching test and sulphate test. The corresponding cements and binders were studied by means of the test on mortar. Mass, dynamic elastic modulus (from resonance frequencies), and expansion have been monitored in order to understand the main mechanisms of degradation, and to find the most sensitive indicators of the damage degree, and the main composition parameters.

The aims of the study were: assessing the sensitivity of the test on mortar and the leaching test, and designing a representative test on concrete. The test is new because $\mathrm{pH}$ is automatically controlled, sulphate concentration is low $(3 \mathrm{~g} / \mathrm{L})$, and it is done on concrete. $\mathrm{pH}$ controlled tests have been done on concrete at high sulphate concentrations (Brown [26]) and on cement pastes at low sulphate concentrations (Planel [6]).The results provided information on the mechanisms by comparing the results of the leaching test and sulphate attacks (Section 4.2.2), and analysing the results of the test from the compositional differences, for each exposure condition.

\section{Characteristics of materials and mixture proportions}

\subsection{Cementitious materials and binders}

The test on mortars was designed to assess chemical resistance of cements or binders of concrete exposed to sodium sulphate attacks. Chemical and physical properties of the cements, ground granulated blast-furnace slag (GGBS) and fly ash (FA) are given in Table 1. FA (Cordemais, France) has low calcium content and can be compared to ASTM Class F fly ash (Lawrence et al., 2005). GGBS (Moerdijk, Netherlands) complies with technical agreement (ATG) in Belgium, BRL 9325 (KIWA) and 9340 (BMC) in the Netherlands and standards NF in France. Three reference cements were used, namely:

- Portland cement CEM I 52.5 R (1) (high $C_{3}$ A content: 10.6\%), Beffes

- Sulphate resisting Portland cement CEM I 52.5 N PM ES (low $C_{3} A$ content: $2 \%$ ), Le Havre

- Sulphate resisting blended cement CEM III I 42.5 PM ES made of $62 \%$ ground granulated blast-furnace slag (GGBS), Le Havre.

Their compositions are significantly different. They may be used as reference binders to study the sensitivity of the test. Three other binders were designed to investigate the influence of the chemical composition of binders on sulphate resistance of concrete:

- Portland cement CEM I 52.5 R (2) (high $C_{3}$ A content: 7.6\%), Saint Pierre La Cour

- Portland cement CEM I 52.5 R + 62\% GGBS.

\subsection{Mortars}

The reference mixes M1, M2, and M3 were designed according to standard NF EN 196-1. The mixtures were made of three parts of normalized sand ( $1350 \mathrm{~g}$ ), one part of cement ( $450 \mathrm{~g}$ ) and half part of water $(225 \mathrm{~g})$. The six previously described binders were respectively used in M1-M6 mortars, keeping a constant w/b ratio.

M7, M8, M9 mortars mixtures are made of the three reference cements to study sensitivity of the test and they have higher $\mathrm{w} / \mathrm{b}$ ratio, in order to accelerate the test. M10, M11, M12 mortars have lower w/ b ratio to study the effect of an increase in compactness on resistance to external sulphate attack. The twelve mortars mixtures given in Table 2 were designed keeping the paste volume (water + binder volumes) constant.

\subsection{Concrete mixtures}

Six concrete mixtures were designed using the same cementitious materials (Table 3). Siliceous sand gravels were used to avoid coupled degradations due to calcium carbonate [12] in case of use of limestone aggregates. Two concrete mixtures $\mathrm{C} 2$ and C4 comply with two levels of prescriptive requirements (XA2 and XA3 exposure classes) from standard NF EN 206-1 [17] for exposure to leaching and sulphate attacks, in terms of minimum Equivalent Binder content (Eq. Binder) and maximum $W_{\text {eff. }} / E q$. Binder ratio. C3 and C6 concrete mixtures do not comply with maximum $\mathrm{SCM} /(\mathrm{SCM}+\mathrm{C})$ ratio, equal to 0.15 in sulphate rich waters or soils. Binder of $\mathrm{C} 5$ concrete mixture is not sulphate-resisting, because its $\mathrm{C}_{3} \mathrm{~A}$ content is higher than $5 \%$. C1 concrete mixture was made of this same cement and has high $W_{\text {eff. }} /$ Eq. Binder ratio. Such mixture often leads to poor resistance to leaching and sulphate attacks [27], but C1 was designed to investigate the sensitivity of the test.

\section{Experimental procedures}

Concrete specimens were exposed to a leaching test and external sulphate attacks in order to assess relevance and sensitivity of these tests and related performance based indicators. Moreover a test was

Table 1

Characteristics of cementitious materials.

\begin{tabular}{|c|c|c|c|c|c|c|}
\hline & \multicolumn{4}{|l|}{ Cements } & \multicolumn{2}{|c|}{$\begin{array}{l}\text { Supplementary cementitious } \\
\text { materials (SCM) }\end{array}$} \\
\hline & CEM III N & CEM I N & CEM I R & $\overline{\text { CEM I R }}$ & $\overline{\text { GGBS }}$ & Fly Ash \\
\hline & PM ES & PM ES & $\overline{(1)}$ & $\overline{(2)}$ & & \\
\hline \multicolumn{7}{|l|}{ Chemical analysis (\%) } \\
\hline $\mathrm{SiO}_{2}$ & 28.60 & 21.25 & 19.45 & 20.40 & 34.49 & 52.5 \\
\hline $\mathrm{Al}_{2} \mathrm{O}_{3}$ & 8.80 & 3.47 & 5.31 & 4.70 & 13.19 & 27.9 \\
\hline $\mathrm{Fe}_{2} \mathrm{O}_{3}$ & 1.07 & 4.23 & 2.50 & 2.95 & 0.40 & 5.6 \\
\hline $\mathrm{CaO}$ & 50.40 & 64.95 & 63.06 & 64.10 & 41.03 & 2.2 \\
\hline $\mathrm{SO}_{3}$ & 2.27 & 2.65 & 3.71 & 3.60 & 0.10 & 0.6 \\
\hline \multicolumn{7}{|c|}{ Compound composition of clinker (\%) } \\
\hline $\mathrm{C}_{3} \mathrm{~S}$ & 66.4 & 73.5 & 65.7 & 63.6 & - & - \\
\hline $\mathrm{C}_{2} \mathrm{~S}$ & 5.6 & 5.5 & 10.0 & 13.4 & - & - \\
\hline $\mathrm{C}_{3} \mathrm{~A}$ & 11.4 & 2.0 & 10.6 & 7.6 & - & - \\
\hline $\mathrm{C}_{4} \mathrm{AF}$ & 5.4 & 12.9 & 8.0 & 9.4 & - & - \\
\hline \multicolumn{7}{|l|}{ Physical properties } \\
\hline Blaine fineness $\left(\mathrm{cm}^{2} / \mathrm{gr}\right)$ & 4300 & 3650 & 4285 & 4130 & 4620 & 3840 \\
\hline Normal comp. strength (MPa) & 57.9 & 62.6 & 65.5 & 65.5 & - & - \\
\hline
\end{tabular}


Table 2

Proportions of mortar mixtures.

\begin{tabular}{|c|c|c|c|c|c|c|c|c|c|c|c|c|}
\hline$\left(\mathrm{kg} / \mathrm{m}^{3}\right)$ & M1 & M2 & M3 & M4 & M5 & M6 & M7 & M8 & M9 & M10 & M11 & M12 \\
\hline Sand & 1484 & 1494 & 1490 & 1490 & 1490 & 1490 & 1484 & 1494 & 1490 & 1484 & 1494 & 1490 \\
\hline \multicolumn{13}{|l|}{ Cement } \\
\hline CEM III PM ES & 495 & & & & & & 419 & & & 591 & & \\
\hline CEM I PM ES & & 498 & & & & 368 & & 420 & & & 597 & \\
\hline CEM I R (1) & & & 497 & & & & & & 420 & & & 593 \\
\hline CEM I R (2) & & & & 497 & 190 & & & & & & & \\
\hline GGBS & & & & & 316 & & & & & & & \\
\hline FA & & & & & & 158 & & & & & & \\
\hline Superplasticizer & & & & & 4.4 & & & & & 8.8 & 8.9 & 9.9 \\
\hline$W_{\text {eff. }}$ & 247 & 249 & 248 & 248 & 237 & 231 & 272 & 273 & 273 & 207 & 209 & 208 \\
\hline$W_{\text {eff. }} /$ Eq. Binder & 0.50 & 0.50 & 0.50 & 0.50 & 0.50 & 0.50 & 0.65 & 0.65 & 0.65 & 0.35 & 0.35 & 0.35 \\
\hline
\end{tabular}

performed on mortars to design a performance test for binders exposed to sulphate attack (Table 4).

\subsection{Leaching test}

The procedure was adapted from existing tests [6,28]. Two identical experimental devices were built in order to study the repeatability and to use the test in a comparative performance based approach (Fig. 1). For each test a $25-\mathrm{mm}$ thick specimen was sawed from a $\emptyset 11 \times 22 \mathrm{~cm}$ specimen. The specimen was circumferentially coated with a waterproof vinylester resin, and hence was exposed to leaching only on its two plane surfaces.

Specimens were immersed in $1.5 \mathrm{~L}$ of demineralised water. The temperature was kept constant at $20^{\circ} \mathrm{C}$ using a jacketed beaker of $2 \mathrm{~L}$ and a regulator. As $\mathrm{pH}$ tends to increase because of the dissolution of portlandite $\mathrm{Ca}(\mathrm{OH})_{2}$, it is controlled by adding appropriate volumes of $0.5 \mathrm{~mol} / \mathrm{L}$ nitric acid solution, through a controlled burette. The set point of $\mathrm{pH}$ was 5 , and the measured value was $5.0 \pm 0.1$. The solution was renewed whenever $30 \mathrm{~mL}$ of nitric acid had been added. The calcium concentration was assessed by atomic absorption spectrometry [29]. C2, C3, C4, C5, C6(1), C6(2) concrete samples were tested

Table 3

Proportions of concrete mixtures.

\begin{tabular}{|c|c|c|c|c|c|c|}
\hline \multirow{2}{*}{$\frac{\text { Exposure classes }}{\left(\mathrm{kg} / \mathrm{m}^{3}\right)}$} & \multirow{2}{*}{$\frac{\mathrm{X} 0}{\mathrm{C} 1}$} & \multicolumn{2}{|l|}{$\mathrm{XA2}$} & \multicolumn{3}{|l|}{ XA3 } \\
\hline & & $\overline{\mathrm{C} 2}$ & C3 & $\overline{C 4}$ & $\mathrm{C} 5$ & C6 \\
\hline \multicolumn{7}{|l|}{ Siliceous gravels Palvadeau } \\
\hline $12.5 / 20$ & 365 & 374 & 358 & 372 & 374 & 366 \\
\hline $8 / 12$ & 268 & 275 & 264 & 274 & 275 & 269 \\
\hline $4 / 8$ & 410 & 421 & 403 & 419 & 421 & 412 \\
\hline \multicolumn{7}{|l|}{ Siliceous sand Palvadeau } \\
\hline $2 / 4$ & 56 & 57 & 55 & 57 & 57 & 56 \\
\hline $1 / 4$ & 238 & 244 & 234 & 243 & 244 & 239 \\
\hline $0.5 / 1$ & 130 & 133 & 127 & 132 & 133 & 130 \\
\hline $0.315 / 1$ & 192 & 197 & 189 & 196 & 197 & 193 \\
\hline $0 / 0.315$ & 103 & 106 & 102 & 105 & 106 & 104 \\
\hline $0 / 0.160$ & 22 & 23 & 22 & 23 & 23 & 23 \\
\hline \multicolumn{7}{|l|}{ Cement (C) } \\
\hline CEM III PM ES & - & - & - & 385 & - & - \\
\hline CEM I PM ES & - & 352 & 280 & - & - & - \\
\hline CEM I R (2) & 280 & - & - & - & 385 & 156 \\
\hline \multicolumn{7}{|l|}{ SCM } \\
\hline Fly ash Cordemais $(k=0.6)$ & - & - & 120 & - & - & - \\
\hline GGBS ECOCEM $(k=0.9)$ & - & - & - & - & - & 254 \\
\hline Effective water ( $\left.W_{\text {eff. }}\right)$ & 205 & 174 & 174 & 154 & 154 & 154 \\
\hline Superplasticizer & 0 & 0.73 & 1.29 & 4.14 & 3.16 & 3.38 \\
\hline Eq. Binder content $(\mathrm{C}+\mathrm{k} . \mathrm{SCM})$ & 280 & 352 & 352 & 385 & 385 & 385 \\
\hline$E_{\text {eff. }} /$ Eq. Binder & 0.73 & 0.49 & 0.49 & 0.40 & 0.40 & 0.40 \\
\hline $\mathrm{SCM} /(\mathrm{SCM}+\mathrm{C})$ & 0 & 0 & 0.30 & 0 & 0 & 0.62 \\
\hline Volume of paste $\mathrm{Vp}\left(\mathrm{L} / \mathrm{m}^{3}\right)$ & 296 & 286 & 308 & 282 & 278 & 293 \\
\hline
\end{tabular}

at $43,56,42,68,45,38$ days after batching respectively. A nitrogen flow was used to avoid carbonation.

\subsection{External sulphate attacks}

\subsubsection{Tests on mortars}

The procedure followed for the test on mortar is close to those described in French standard NF P 18-837 [22] and ASTM standard C 1012 [21]. It consists in immersing prismatic mortar specimens in concentrated sodium sulphate solution. For each mortar mixture, six $4 \times 4 \times 16 \mathrm{~cm}^{3}$ prismatic specimens and six $2 \times 2 \times 16 \mathrm{~cm}^{3}$ specimens were cast and sealed cured for $24 \mathrm{~h}$. They were stored in water for 14 days then for 14 days at $40{ }^{\circ} \mathrm{C}$. Three control specimens were vacuum saturated with tap water and immersed in water and three others specimens were saturated with sodium sulphate solution and immersed in the solution. The sulphate concentration is $30 \mathrm{~g} / \mathrm{L}$. The solution was prepared using demineralised water and renewed once a month. $2 \times 2 \times 16 \mathrm{~cm}^{3}$ specimens have gauge studs to measure expansion with length comparators. The elastic modulus was determined on $4 \times 4 \times 16 \mathrm{~cm}^{3}$ prisms with a Grindosonic apparatus. This device gives the frequency of a vibration created by a slight shock on the sample. The elastic modulus is calculated from this frequency with the Spinner and Teft model [30]. All tests were carried out on three samples and the given results are average values.

\subsubsection{Tests on concrete}

$7 \times 7 \times 28 \mathrm{~cm}^{3}$ prismatic concrete specimens were sealed cured until they reach $50 \%$ of required compressive strength (NF EN 206-1) for the corresponding exposure class (X0, XA2, XA3) and stored at $20{ }^{\circ} \mathrm{C}$ and $50 \% \mathrm{RH}$. After 28 days they were immersed in two different sodium sulphate solutions [31]. Solutions were made of demineralised water and sodium sulphate. The sulphate concentration of the first solution was $3 \mathrm{~g} / \mathrm{L}$, and $\mathrm{pH}$ is controlled using $0.02 \mathrm{~mol} / \mathrm{L}$ sulphuric acid solution. The sulphate concentration of the second solution was $30 \mathrm{~g} / \mathrm{L}$, and $\mathrm{pH}$ is controlled using $44 \mathrm{~g} / \mathrm{L}$ sodium sulphate $+0.04 \mathrm{~mol} / \mathrm{L}$ sulphuric acid solution. Solutions were renewed every month. Mass, length and elastic modulus of concrete samples were monitored.

Table 4

Experimental program.

\begin{tabular}{|c|c|c|c|}
\hline & & Mortar & Concrete \\
\hline \multirow[t]{2}{*}{$\begin{array}{l}\text { External } \\
\text { sulphate attacks }\end{array}$} & Specimens & $\begin{array}{l}\text { Prisms: } \\
2 \times 2 \times 16 \mathrm{~cm}^{3} \text {, } \\
4 \times 4 \times 16 \mathrm{~cm}^{3}\end{array}$ & $\begin{array}{l}\text { Prisms: } \\
7 \times 7 \times 28 \mathrm{~cm}^{3}\end{array}$ \\
\hline & $\begin{array}{l}\text { Sulphate } \\
\text { concentration } \\
{\left[\mathrm{SO}_{4}^{2-}\right]}\end{array}$ & $30 \mathrm{~g} / \mathrm{L}$ & $3 \mathrm{~g} / \mathrm{L}, 30 \mathrm{~g} / \mathrm{L}$ \\
\hline Leaching & Specimens & - & $\begin{array}{l}\text { Cylinder: } \\
\emptyset 11 \times 2.5 \mathrm{~cm}\end{array}$ \\
\hline
\end{tabular}




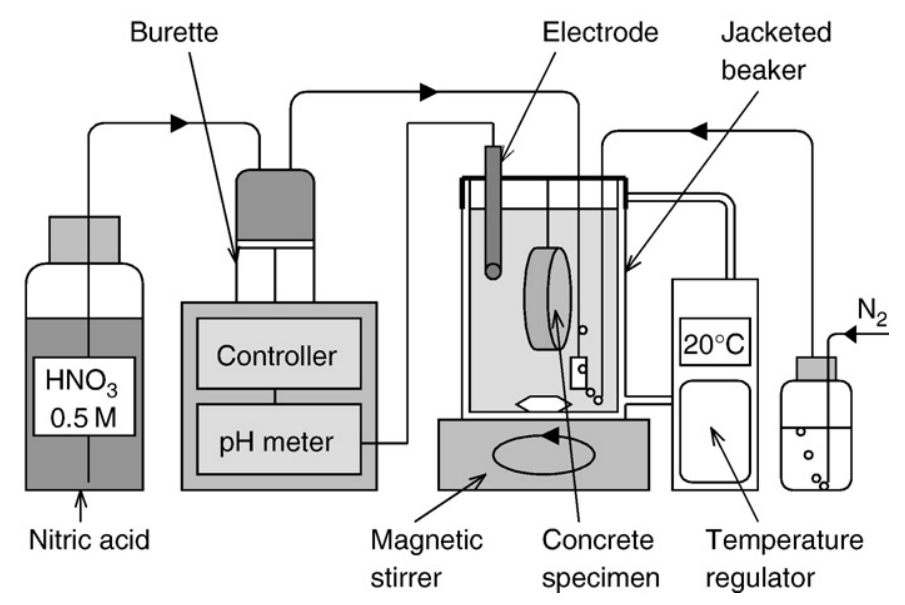

Fig. 1. Schematic diagram of leaching test.

\section{Results and discussion}

\subsection{Results of leaching tests}

The quantity of leached hydroxide ions was assessed through the added volumes of nitric acid $\mathrm{HNO}_{3}$ solution, and that of leached calcium by the titration of the solutions. These quantities are plotted against square root of time in Figs. 2 and 3.

The parameters of leaching kinetics may be deduced from quantity of leached ions versus square root of time curves. Steady state was assumed to be reached after 1 day. Corresponding parameters are given in Table 5, for the following Eq. (1):

$N(t)=a \cdot \sqrt{t}+b$.

Ratios of leaching rates $a_{\mathrm{OH}} / a_{\mathrm{Ca}}$ are close to 2 (Table 5) suggesting leaching had mainly come from dissolution of portlandite $\mathrm{Ca}(\mathrm{OH})_{2}$ (Eq. (2)).

$\mathrm{Ca}(\mathrm{OH})_{2}+2 \mathrm{H}_{3} \mathrm{O}^{+} \rightarrow \mathrm{Ca}^{2+}+4 \mathrm{H}_{2} \mathrm{O}$

Ratios are actually above 2, so a part of leached calcium ions could come also from $\mathrm{CSH}$.

After taking out from immersion phenolphthalein solution was sprayed over a fresh fracture to measure the damaged depth using the

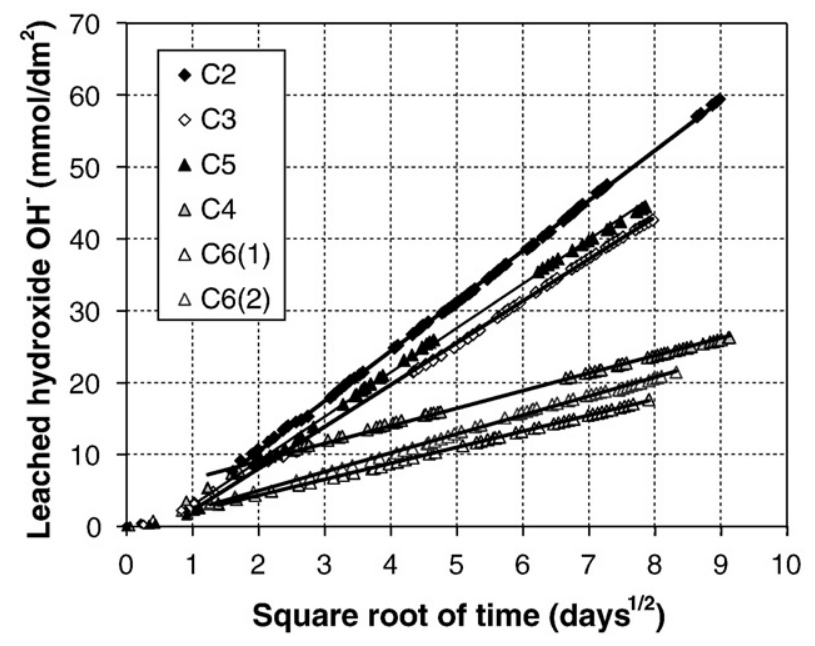

Fig. 2. Leached hydroxide ions.

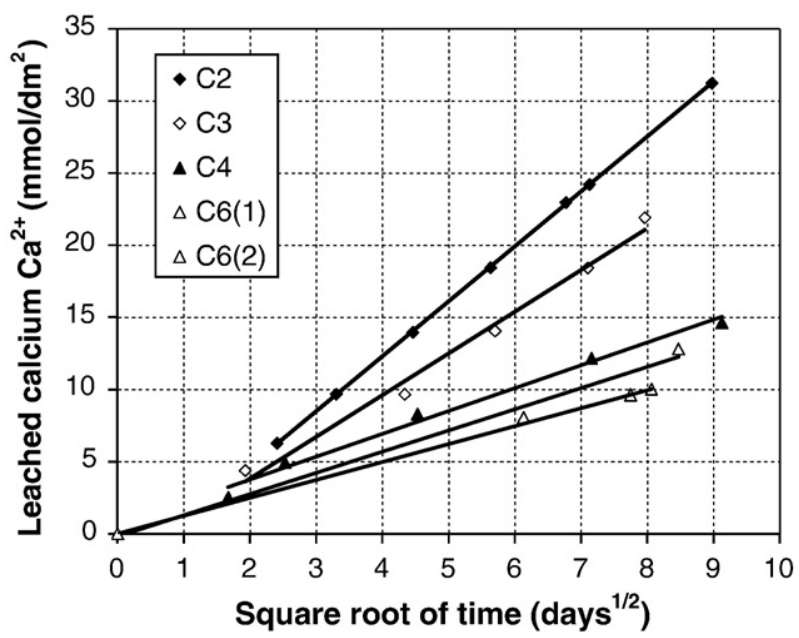

Fig. 3. Leached calcium ions.

coloration front. Results in Table 6 show that corroded layer is very thin, for all concrete mixtures, so a more precise and sensitive criterion was looked for. Assuming that calcium ions only came from binder and that no portlandite remained in corroded layers, equivalent damaged depths may be calculated, dividing the total amount of leached calcium by the theoretical initial total calcium content of binder. From experimental data of the leaching test and $\mathrm{CaO}$ content of the cementitious materials, the following ratio can be calculated and give an equivalent damaged depth (EDD). The Total leached calcium is the ratio of the total leached calcium on specimen surface area (in $\mathrm{mol} / \mathrm{m}^{2}$ ) and Initial calcium content in binder is in $\mathrm{mol} / \mathrm{m}^{3}$.

$E D D=\frac{\text { Total leached calcium }}{\text { Initial calcium content in binder }}$

Equivalent damaged depths of $\mathrm{C} 3$ and $\mathrm{C} 5$ concrete samples were assessed assuming a ratio of leaching rates $a_{\mathrm{OH}} / a_{\mathrm{Ca}}$ equal to 2 .

From microstructural analyses on concrete specimen after the same testing procedure, the equivalent damaged depth would actually underestimate the damaged depth, because the corroded layer was not totally decalcified, which was an assumption of the previous calculation [29].

The amounts of leached calcium or hydroxide ions can be considered as criteria for a comparative approach of durability of concrete. The

Table 5

Parameters of leaching kinetics.

\begin{tabular}{llrrrrrr}
\hline & & \multicolumn{1}{c}{ C2 } & \multicolumn{1}{c}{ C3 } & C4 & C5 & C6 (1) & C6 (2) \\
\hline $\mathrm{OH}$ & $a\left(\mathrm{mmol} / \mathrm{dm}^{2} / \mathrm{d}^{1 / 2}\right)$ & 6.97 & 5.82 & 2.45 & 6.17 & 2.23 & 2.64 \\
& $b\left(\mathrm{mmol} / \mathrm{dm}^{2}\right)$ & -3.44 & -3.59 & 4.19 & -3.23 & -0.15 & -0.35 \\
$\mathrm{Ca}$ & $a\left(\mathrm{mmol} / \mathrm{dm}^{2} / \mathrm{d}^{1 / 2}\right)$ & 3.81 & 2.90 & 1.59 & - & 1.24 & 1.48 \\
& $b\left(\mathrm{mmol} / \mathrm{dm}^{2}\right)$ & -2.95 & -1.97 & 0.58 & - & 0 & -0.21 \\
\hline
\end{tabular}

Table 6

Experimental and equivalent damaged depths.

\begin{tabular}{|c|c|c|c|c|c|c|}
\hline & $\mathrm{C} 2$ & C3 & $\mathrm{C} 4$ & C5 & C6 (1) & C6 (2) \\
\hline $\begin{array}{l}\text { Total leached calcium } \\
\text { at } 60 \text { days }\left(\mathrm{mmol} / \mathrm{dm}^{2}\right)\end{array}$ & 26.6 & 21.0 & 12.9 & 22.3 & 9.1 & 10.5 \\
\hline $\begin{array}{l}\text { Initial calcium content in } \\
\text { binder }\left(\mathrm{mol} / \mathrm{dm}^{3}\right)\end{array}$ & 4.08 & 3.33 & 3.47 & 4.41 & 3.65 & 3.65 \\
\hline Equivalent damaged depth EDD (mm) & 0.65 & 0.63 & 0.37 & 0.51 & 0.25 & 0.29 \\
\hline $\begin{array}{l}\text { Experimental damaged depth } \\
\quad \operatorname{ExpDD}(\mathrm{mm})\end{array}$ & 0.5 & 0.5 & $<0.5$ & $<0.5$ & $<0.5$ & $<0.5$ \\
\hline
\end{tabular}



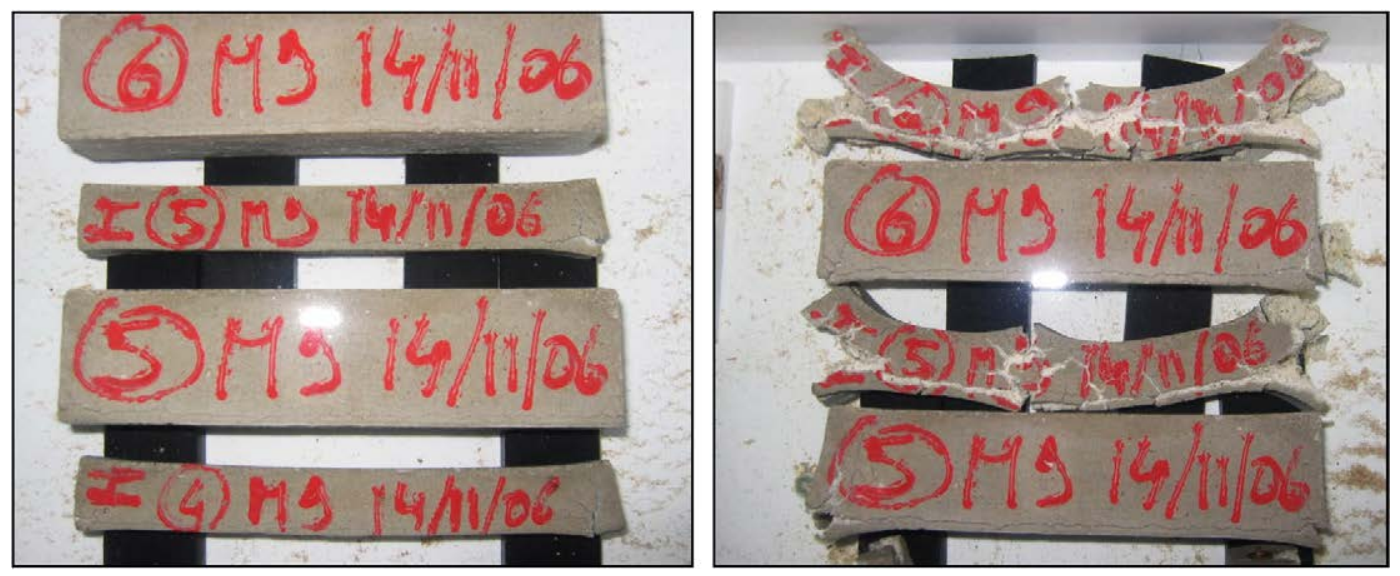

Fig. 4. M9 mortar specimens after 105 and 150 days in $30 \mathrm{~g} / \mathrm{L}$ sulphate solution.

leaching rates of C6 (1) and C6 (2) concrete specimens were 8.4\% higher or lower than the mean value for the two tests, which was $2.44 \mathrm{mmol} /$ $\mathrm{dm}^{2} /$ day $^{1 / 2}$, so significant differences may be deduced from experimental results.

Leaching increased with an increase in Water/Binder ratio, which can be explained by corresponding variations of porosity and diffusivity. But this does not account for all the differences. C3 should have a better behaviour than $\mathrm{C} 2$ concrete, and leaching rate has reduced by $18 \%$. So incorporating $30 \%$ of FA in binder would improve resistance to leaching, and behaviour would not only depend on porosity but on chemical composition of binder. Blended cements or binder incorporating such pozzolanic materials actually produce less portlandite, with equal or enhanced compactness of the matrix.

Among the concrete tested, the concrete with high amounts of GGBS (62\%) leads to good resistance to leaching. C4 and C6 concrete mixtures showed the lowest leaching rates and total amounts of leached calcium and hydroxide ions. They have the same leaching rates (respectively 2.45 and $2.44 \mathrm{mmol} / \mathrm{dm}^{2} /$ day). So including GGBS in concrete mixture instead of using blended cement had not significant effect with these materials.

Finally three indicators can be assessed from the test, namely: the Total leached calcium at the end of the test, the Experimental Damaged Depth and the Equivalent Damaged Depth. For a given type of aggregates, classifications of performances based on these three indicators were the same. Equivalent Damaged Depth is assessed from the hypothesis that the calcium is totally leached in damaged depth. The good correlation between the Experimental Damaged Depth and the Equivalent Damaged Depth suggests that the hypothesis is mainly true. Classifications of performances from the first indicator, Total leached

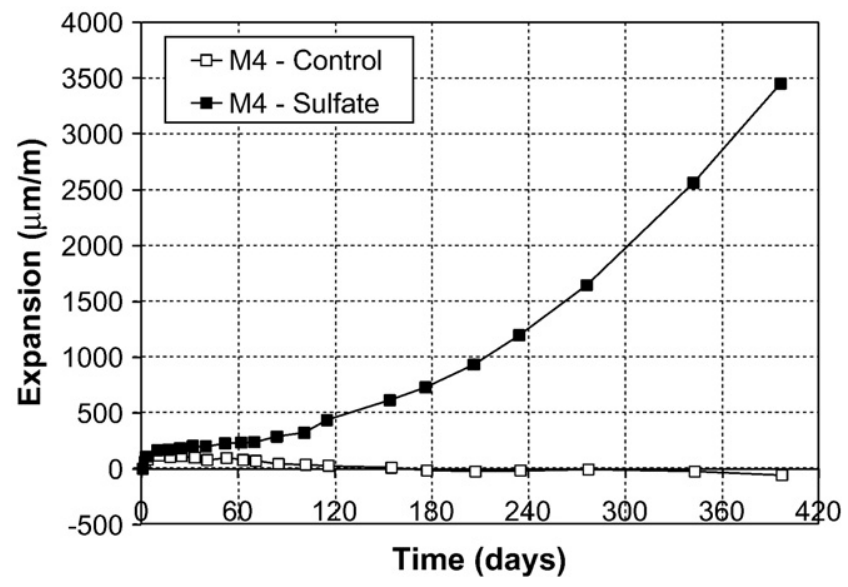

Fig. 5. Expansion of $2 \times 2 \times 16 \mathrm{~cm}^{3}$ specimens. calcium, are the same because the variations of total leached calcium are higher than the variations of initial calcium content. Higher initial calcium concentrations in binder came from lower water/cement ratios and lower diffusivities and thus lead to better resistance to leaching.

\subsection{Results of external sulphate attack tests}

We can suppose sulphate ions are likely to react with portlandite and $\mathrm{C}_{3} \mathrm{~A}$-rich hydration products, according to the following equations [15]:

$\mathrm{Ca}(\mathrm{OH})_{2}+\mathrm{SO}_{4}^{2-}+2 \mathrm{H}_{3} \mathrm{O}^{+} \rightarrow \mathrm{CaSO}_{4}, 2 \mathrm{H}_{2} \mathrm{O}+2 \mathrm{H}_{2} \mathrm{O}$.

Gypsum $\left(\mathrm{CaSO}_{4}, 2 \mathrm{H}_{2} \mathrm{O}\right)$ is referred to as $\mathrm{CS}_{2} \mathrm{H}_{2}$ and $\mathrm{H}_{2} \mathrm{O}(\mathrm{H})$ and ettringite as $\mathrm{C}_{6} \mathrm{AS}_{3} \mathrm{H}_{32}$ in the following equations:

$\mathrm{C}_{4} \mathrm{AH}_{13}+3 \mathrm{C} \overline{\mathrm{S}} \mathrm{H}_{2}+14 \mathrm{H} \rightarrow \mathrm{C}_{6} \mathrm{AS}_{3} \mathrm{H}_{32}+\mathrm{CH}$

$\mathrm{C}_{4} \mathrm{~A} \overline{\mathrm{S}} \mathrm{H}_{12}+2 \mathrm{C} \overline{\mathrm{S}} \mathrm{H}_{2}+16 \mathrm{H} \rightarrow \mathrm{C}_{6} \mathrm{AS}_{3} \mathrm{H}_{32}$

$\mathrm{C}_{3} \mathrm{~A}+3 \mathrm{C} \overline{\mathrm{S}} \mathrm{H}_{2}+26 \mathrm{H} \rightarrow \mathrm{C}_{6} \mathrm{~A} \overline{\mathrm{S}}_{3} \mathrm{H}_{32}$

\subsubsection{External sulphate attacks on mortars}

As shown on Fig. 4, some samples have shown the typical expansion and cracking of concrete exposed to sodium sulphate

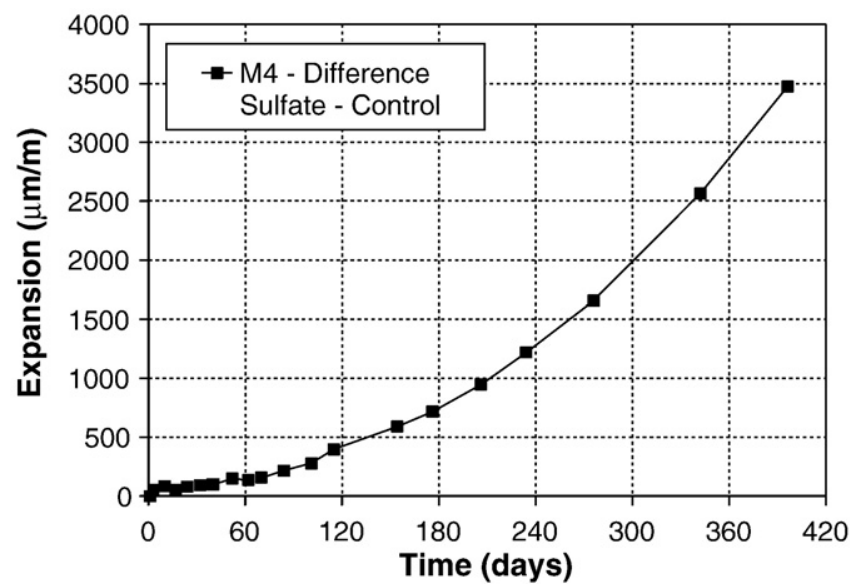

Fig. 6. Expansion of $2 \times 2 \times 16 \mathrm{~cm}^{3}$ specimens. Difference between sulphate and control specimens. 


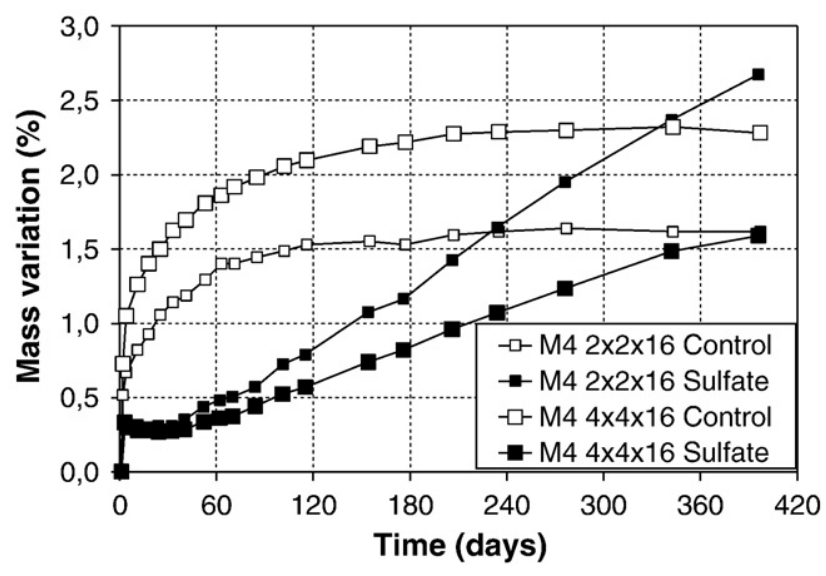

Fig. 7. Mass variations of mortar specimens.

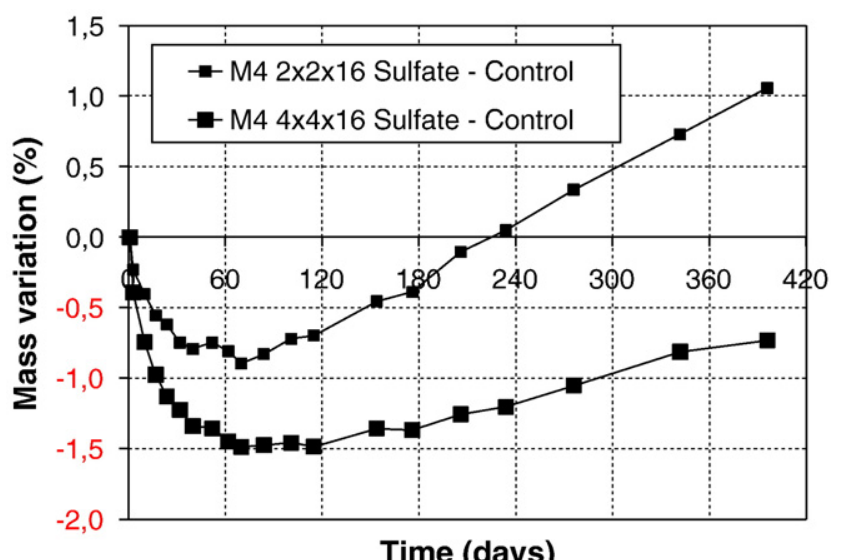

Fig. 8. Mass variations of mortar specimens. Difference between sulphate and control specimens.

solution with high sulphate concentration, i.e. equal to $20 \mathrm{~g} / \mathrm{L}$ or higher [8].

Expansion was observed before cracking by the monitoring of length (Figs. 5 and 6) and mass (Figs. 7 and 8). As absorption of water and hydration are likely to occur after immersion, differences between measures on control specimens and specimens exposed to sulphate solution were calculated to focus on the effects of sulphate ions. They are plotted in Figs. 6 and 8. Relative mass decrease occurs during the period of latency, when no significant expansion occurred. The mass decrease is due to leaching. The mass increase is due to swelling caused by gypsum and/or ettringite formation in damaged mortar specimens. As the sulphate attack is external, the effect of the Exposed surface/Specimen volume ratio is important and this can be seen in Figs. 4, 7 and 8, where damage and mass increase are greatest in the specimens with the higher surface/volume ratio.

Elastic modulus (Fig. 9) does not appear as a sensitive indicator of damage during the first stage, as the modulus of attacked specimens remains equal or higher than modulus of control specimens even if significant expansion and damage can be observed. Lee et al. [32] and Sahmaran et al. [27] have also shown the positive effect of sulphate attack on mechanical properties, before they finally decrease. Decrease of elastic modulus became significant after about 120 days (Figs. 9 and 10), but mass variation appeared earlier (Fig. 7) so this would be a better indicator for a performance test.

Mortar mixtures M1 to M6 were designed keeping water/binder ratio and paste volume constant. Mass variations and expansions of these mortars are plotted in Figs. 11 and 12. Even mortar including

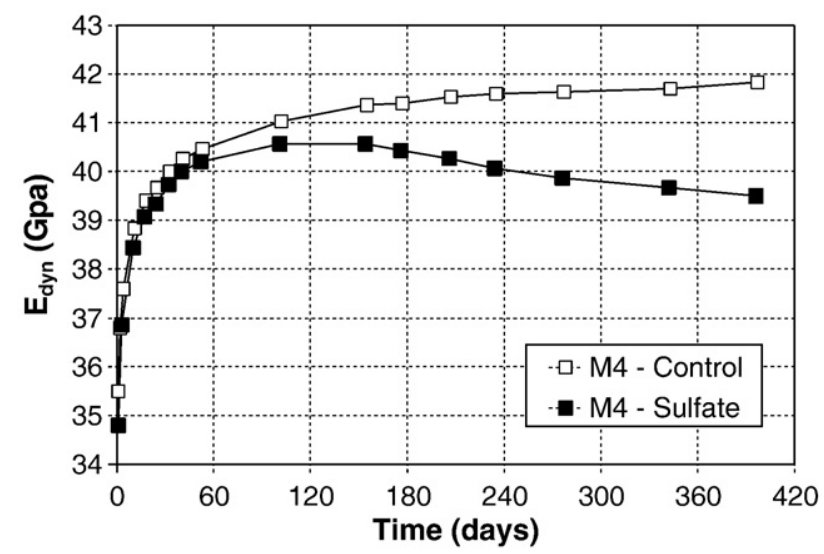

Fig. 9. Elastic modulus of $4 \times 4 \times 16 \mathrm{~cm}^{3}$ specimens.

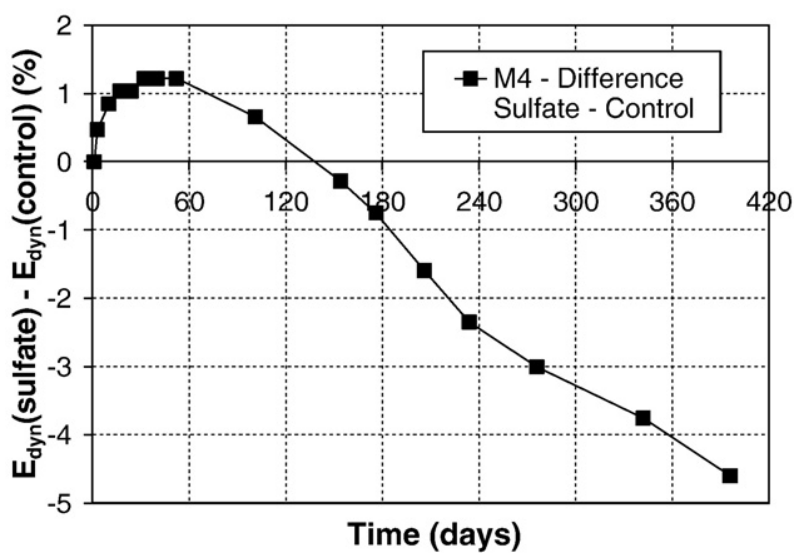

Fig. 10. Elastic modulus of $4 \times 4 \times 16 \mathrm{~cm}^{3}$ specimens. Difference between sulphate and control specimens.

sulphate resisting cement (M2) shows significant expansion (Fig. 12), which has already been observed in other studies using the same kind of test on mortar [27]. Tian and Cohen [33] have shown that gypsum could also cause expansion in sulphate environments. So analysis of microstructure is necessary to know whether expansion is actually due to ettringite. Irassar [14] has found high gypsum concentration in the outer layer of damaged specimens by means of XRD analysis. An ettringite inner layer has also been found on the same samples, but

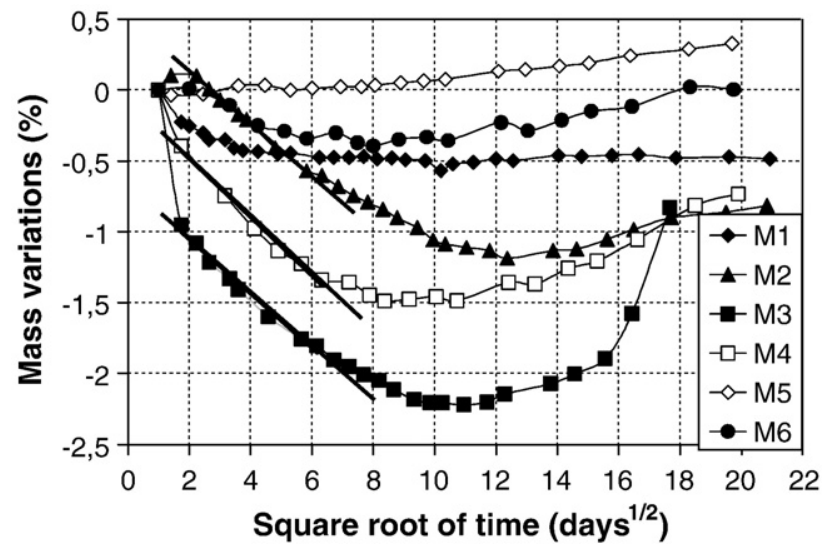

Fig. 11. Mass variations of $4 \times 4 \times 16 \mathrm{~cm}^{3}$ specimens. Difference between sulphate and control specimens. Water/Binder $=0.50$. 


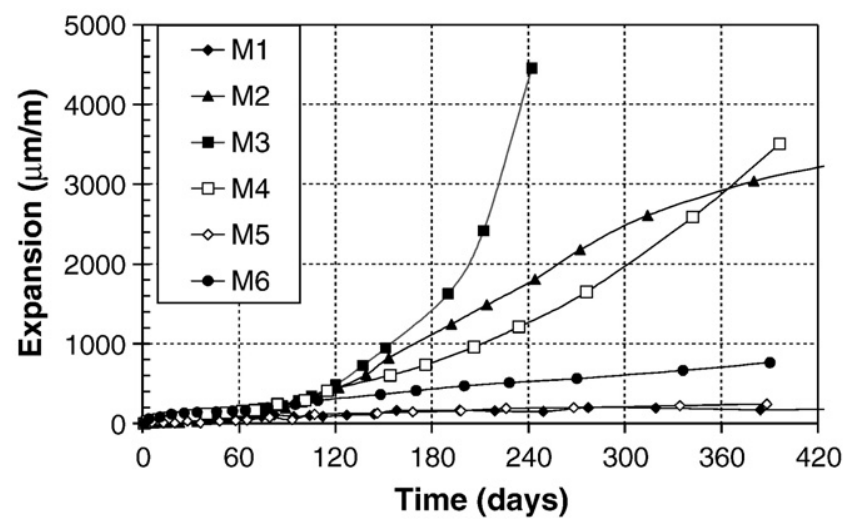

Fig. 12. Expansion of $2 \times 2 \times 16 \mathrm{~cm}^{3}$ specimens. Difference between sulphate and control specimens. Water $/$ Binder $=0.50$.

gypsum could actually play an important part in the mechanism of degradation at such high sulphate concentrations.

The two stages of the degradation may be distinguished in Figs. 11 and 12. The first step corresponds to the period of latency, when no significant expansion can be measured. The second stage corresponds to significant expansion. It starts at about 60 days for M4 mortar specimens.

The difference between the mass variations of control and damaged specimens is plotted against the square root of time, which shows a linear dependency. This can be clearly seen for mortars M2, M3, and M4. That corresponds to leaching and diffusion-reaction processes between sulphate solution and hydration products, mainly portlandite $\mathrm{Ca}(\mathrm{OH})_{2}[6]$. This could explain why the cements used in mortars M2, M3, and M4 showed the highest expansion, even if cement used in M2 is considered as sulphate resisting. The three cements actually have approximately the same proportion of $\mathrm{CaO}$ and high proportions of $C_{3} S$. They produce comparatively greater amounts of portlandite on hydration than blended cements or binders. Leaching of portlandite can thus increase ingress of sulphate ions in cement matrix. Moreover reaction with sulphate is likely to produce more gypsum $\left(\mathrm{CaSO}_{4}\right)$ and more ettringite $\left(\mathrm{C}_{3} \mathrm{~A} .3 \mathrm{CaSO}_{4} \cdot 32 \mathrm{H}_{2} \mathrm{O}\right)$, which are responsible for expansion and damage.

Gypsum has actually been observed on cracked mortar samples. Fig. 13 shows scanning electron microscopy and energy dispersive spectroscopy (SEM/EDS) analysis on M4 polished mortar sample. EDS analysis (Table 7, Fig. 14) was performed at accelerating voltage of $20 \mathrm{keV}$ and takeoff angle of $37^{\circ}$. High silicon concentrations come from siliceous aggregate and calcium comes from cement paste. High concentrations of sulphur can be observed in cracks, especially between paste and aggregates. Normalized weight concentrations and atomic proportions given by quantitative analysis are closed to composition of gypsum $\mathrm{CaSO}_{4}$, and $\mathrm{Ca} / \mathrm{S}$ ratio is equal to 1.1. This confirms the part played by gypsum in expansion due to sulphate attacks.

Fig. 15 confirms the influence of the chemical composition of binder on expansion of mortar. Expansion after 180 and 360 days has been plotted as a function of the sum of $\mathrm{CaO}$ and $\mathrm{Al}_{2} \mathrm{O}_{3}$ proportions, as these two oxides are the main compounds of $C_{3} S$ and $C_{3} A$, so they potentially lead to production of ettringite and gypsum in sulphaterich environments. Two behaviours can be distinguished. Portland cements, i.e. the two high- $\mathrm{C}_{3} \mathrm{~A}$ cements and the sulphate-resisting cement, have the same $\mathrm{CaO}+\mathrm{Al}_{2} \mathrm{O}_{3}$ content (68.4\%). They showed significant expansions for water/binder ratios equal or higher than 0.5. Even if $C_{3} A$ content is known as a major parameter, this result
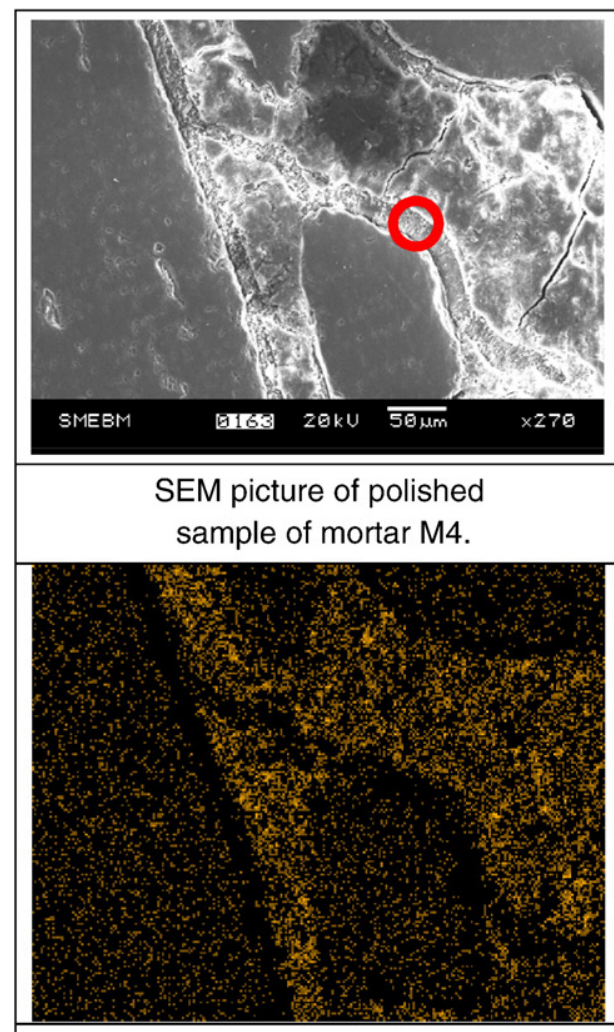

EDS analysis: Aluminium relative concentrations.
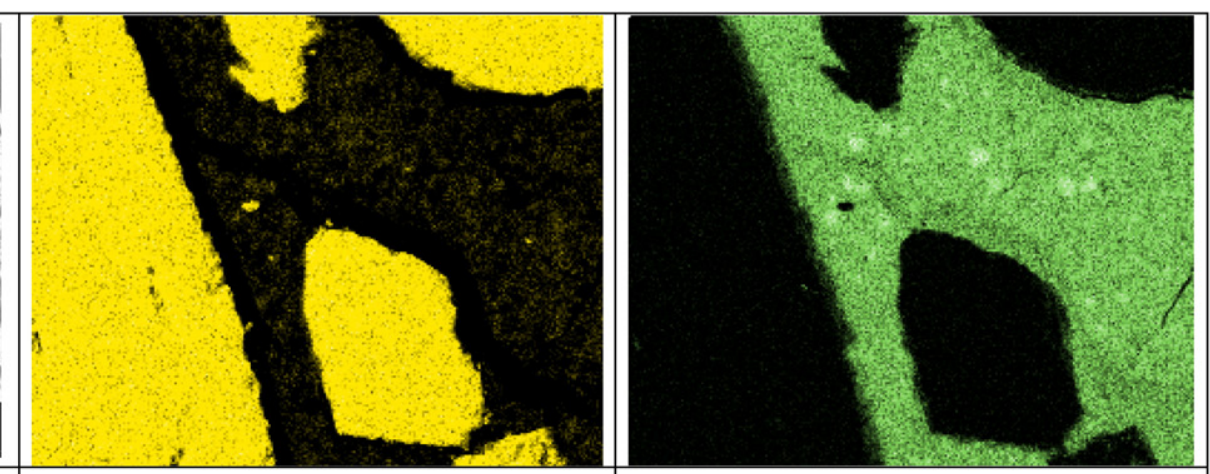

EDS analysis: Silicon relative concentrations.

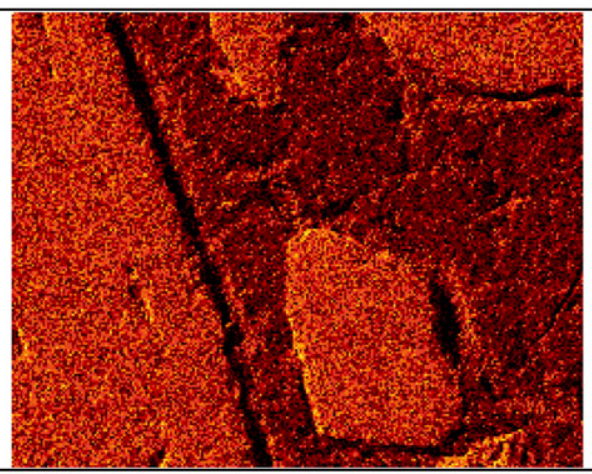

EDS analysis: Oxygen relative concentrations.
EDS analysis: Calcium relative concentrations.

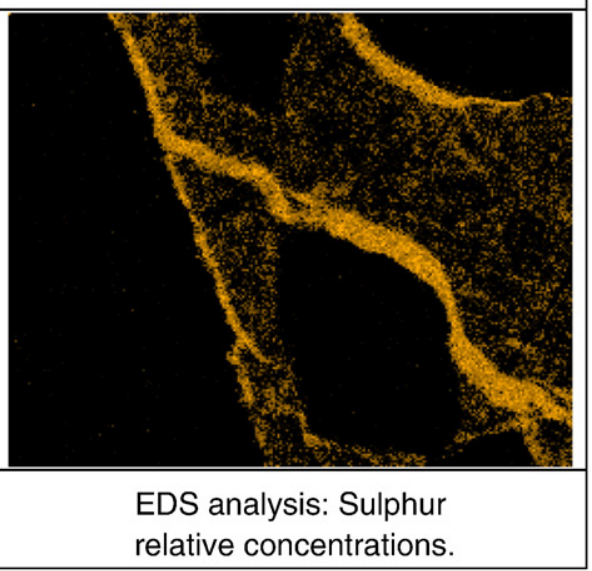

Fig. 13. Scanning electron microscopy and energy dispersive spectroscopy analysis on M4 mortar sample. 
Table 7

EDS analysis on M4 mortar sample (circled zone): quantitative analysis.

\begin{tabular}{lcccc}
\hline Element & Normalized & Precision & Atomic prop. & Line \\
\cline { 2 - 4 } & conc. (wt.\%) & & $(\%)$ & \\
\hline $\mathrm{O}$ & 58.7 & 3.75 & 75.8 & K line \\
$\mathrm{Al}$ & 0.31 & 0.16 & 0.23 & K line \\
$\mathrm{Si}$ & 3.70 & 0.34 & 2.72 & K line \\
$\mathrm{S}$ & 15.7 & 0.59 & 10.2 & K line \\
$\mathrm{Ca}$ & 21.7 & 0.78 & 11.2 & K line \\
Total & 100.00 & & 99.99 & \\
\hline
\end{tabular}

suggests that $\mathrm{C}_{4} \mathrm{AF}$ could also play an important part. Mortars made of the same cements but with lower water/binder ratio (0.35) did not show any significant expansion. Reducing the water/binder ratio actually improves strength and resistance to the ingress of the sulphate ions by diffusion [27,34]. The slag cement and the binders made of Portland cement and slag (62\%) or fly ash (30\%) showed much lower expansion, even for high water/binder ratios [35-37]. But expansion of M6 $(30 \% \mathrm{FA}, w / b=0.50)$ and M7 (62\% GGBS, $w / b=0.65)$ had not stabilized after 420 days, so $w / b$ ratio and chemical composition of binder are both important parameters and slight variations can completely change behaviour of mortars or concrete, from stabilization to unlimited expansion. The water-binder ratio influences the diffusivity and the strength of mortar or concrete. The $\mathrm{CaO}+\mathrm{Al}_{2} \mathrm{O}_{3}$ content is related to the potential amount of gypsum and ettringite and the forces due to formation of these products. The result of the test is global and influenced by both factors, namely: the forces coming from the formation of expansive products, and the resistance (tensile strength) of the material. The diffusivity influences the kinetics. Slight changes of composition parameters can thus significantly affect the potential expansion or the strength, thus the behaviour of mortar.

The behaviours distinguished in Fig. 15 are consistent with expansion data from ASTM C 1012 tests. According to ASTM Subcommittee C01-29 [38], cements satisfying the expansion limits of $0.10 \%(1000 \mu \mathrm{m} / \mathrm{m})$ and $0.05 \%(500 \mu \mathrm{m} / \mathrm{m})$ at 26 weeks are considered as moderate sulphate resistant and high sulphate resistant, respectively and the expansion limits of $0.10 \%(1000 \mu \mathrm{m} / \mathrm{m})$ at 52 weeks are considered as high sulphate resistant [27]. But expansion at a given time does not give information on future stability of mortar or concrete. Monteiro and Kurtis [39] have proposed a predictive approach based on experimental asymptotic analysis, from the 40-year study on concrete conducted by the U.S. Bureau of Reclamation (USBR).

During the first stage of sulphate attacks, leaching occurs and the dominant phenomenon is the diffusion-reaction as shown in Fig. 11. During the second stage of expansion, other phenomena occur such as the formation of expansive products, damage and, in some cases,

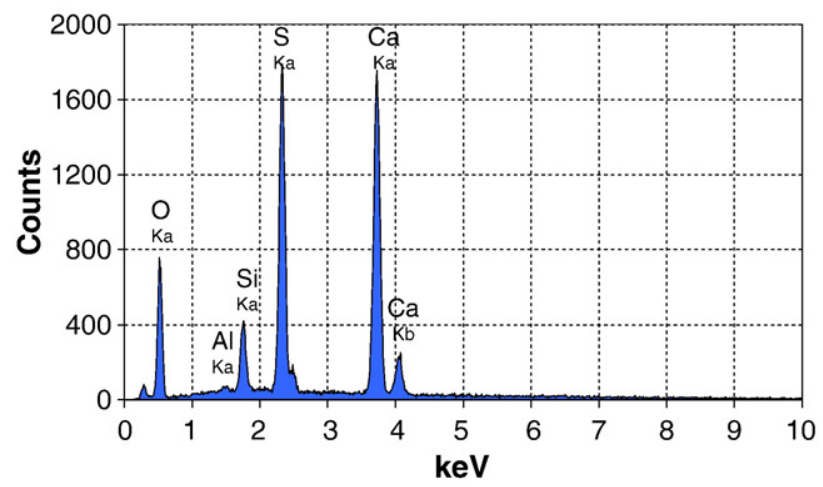

Fig. 14. EDS analysis on M4 mortar sample (circled zone): spectrum.

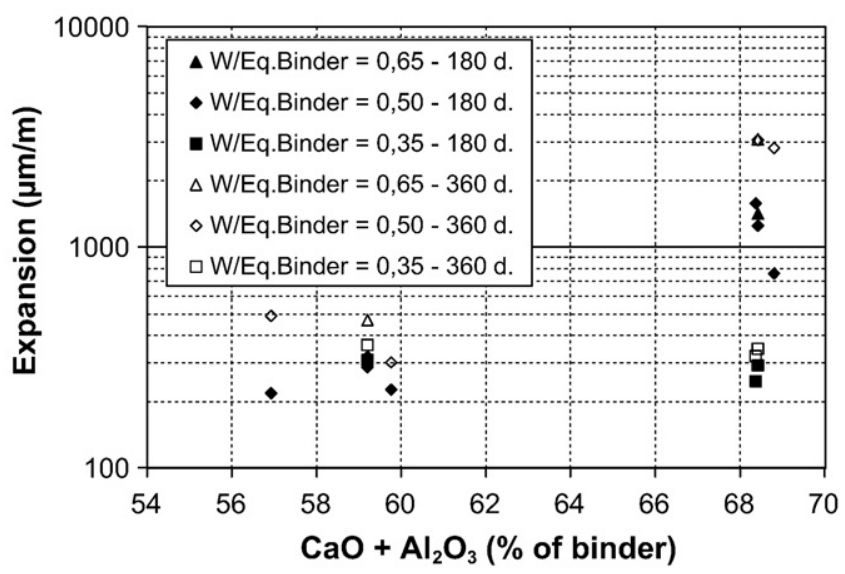

Fig. 15. Influence of chemical composition of binder on expansion of mortar.

coupling with hydration and healing. The aim of this approach is to obtain similitude laws for phenomena from experimental results [39]. The scaling law for the expansion $\varepsilon$ of concrete or mortar is expressed as follow:

$\varepsilon=K\left(t-t_{0}\right)^{\alpha}$

where $K$ is a constant, $t$ the time, $t_{0}$ the effective origin of time and $\alpha$ the scaling exponent. $\alpha$ can be assessed by plotting $\log (\varepsilon)$ as a function $\log (t)$. Therefore the curve $\varepsilon^{1 / \alpha}$ versus $t$ is linear (Fig. 16). The value of $t_{0}$ is given by the intercept with the horizontal axis. The same graph provides the initiation time $t_{\mathrm{i}}$, which represents the initiation of the expansion stage.

Mortars M1, M5, M10, M11 and M12 did not show expansion. Instead, they show saturation behaviour, as expansion increases but remains limited. Forces due to expansion of the products of sulphate attack are lower than the strength of the material. The saturation process repeats itself (Fig. 17). It was defined by the following equation:

$\varepsilon=\varepsilon_{\lim }\left(1-e^{-\beta t}\right)$.

Based on data from the USBR tests on concrete, Monteiro and Kurtis [39] defined a potential damage Pd to predict the initiation time or saturation behaviour from the composition of concrete and cement:

$P d=\mathrm{C}_{3} \mathrm{~A}^{1.39} \mathrm{C}_{3} \mathrm{~S}^{2.9} \mathrm{C}_{4} \mathrm{AF}^{0.77}(w / c)^{7.80}$

As shown in Fig. 18, this model gives a good assessment for the behaviour of mortars exposed to the same kind of test. It is difficult to

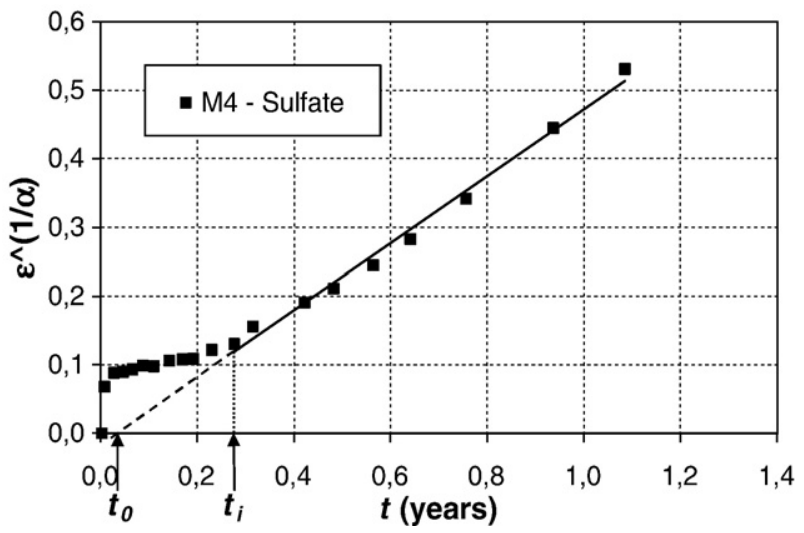

Fig. 16. Assessment of $t_{0}$ and $t_{\mathrm{i}}$ of self-similar curve. 


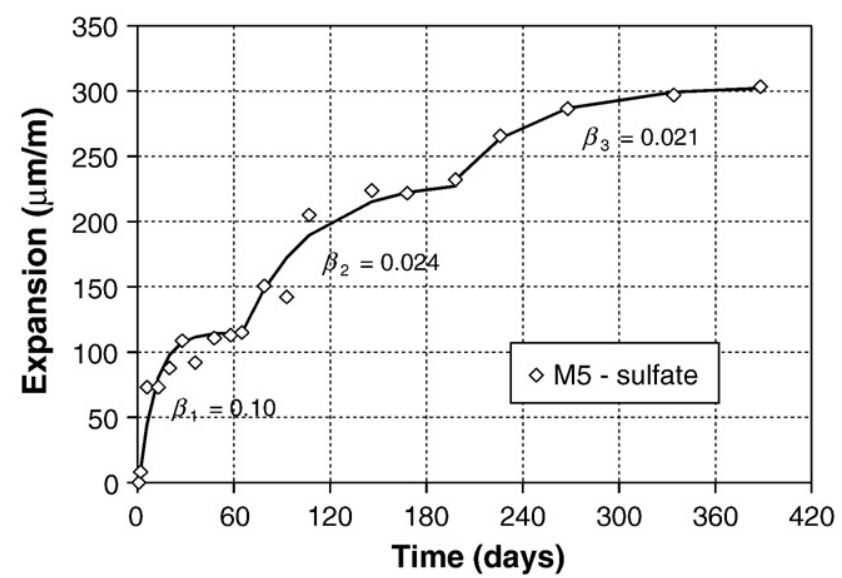

Fig. 17. Saturation curves of mortar M5.

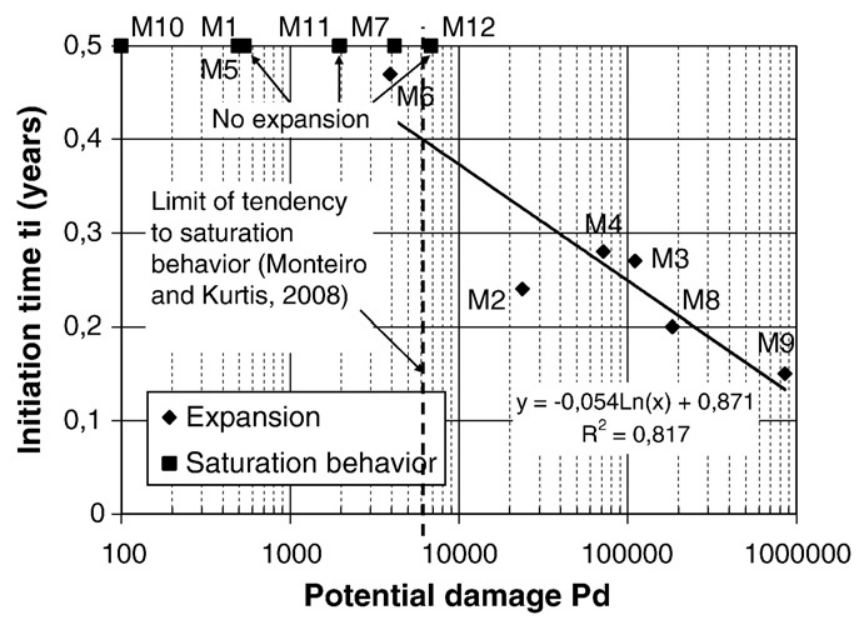

Fig. 18. Analysis of expansion data by scaling law.

find the limit of tendency to saturation behaviour. For instance, M12 mortar has not shown significant damage but saturation behaviour, whereas M6 mortar has shown self-similar behaviour. So slight changes in cement properties or $w / b$ can significantly affect performance of concrete exposed to sulphate attacks according to this test procedure $[27,39]$. All expansion data are presented in Table 8.

Results from this study on mortars are consistent with other studies on the same test. As the sulphate concentration could modify the conditions of sulphate attack, especially the relative amounts of

Table 8

Analysis of expansion data.

\begin{tabular}{|c|c|c|c|c|}
\hline & $\alpha$ & $t_{0}$ & $t_{\mathrm{i}}$ & $P d$ \\
\hline & $\overline{\text { Measured }}$ & $\overline{\text { Origin of time }}$ & $\overline{\text { Initiation time }}$ & $\overline{\text { Potential of damage }}$ \\
\hline$\overline{\mathrm{M} 1}$ & - & - & - & 536 \\
\hline M2 & 1.70 & 0.016 & 0.24 & 22,315 \\
\hline M3 & 2.47 & 0.019 & 0.27 & 110,622 \\
\hline M4 & 1.68 & 0.032 & 0.28 & 71,718 \\
\hline M5 & - & - & - & 492 \\
\hline M6 & 1.16 & 0.001 & 0.47 & 3671 \\
\hline M7 & - & - & - & 4150 \\
\hline M8 & 1.44 & 0.048 & 0.20 & 172,729 \\
\hline M9 & 3.08 & 0.045 & 0.15 & 856,252 \\
\hline M10 & - & - & - & 33 \\
\hline M11 & - & - & - & 1382 \\
\hline M12 & - & - & - & 6849 \\
\hline
\end{tabular}

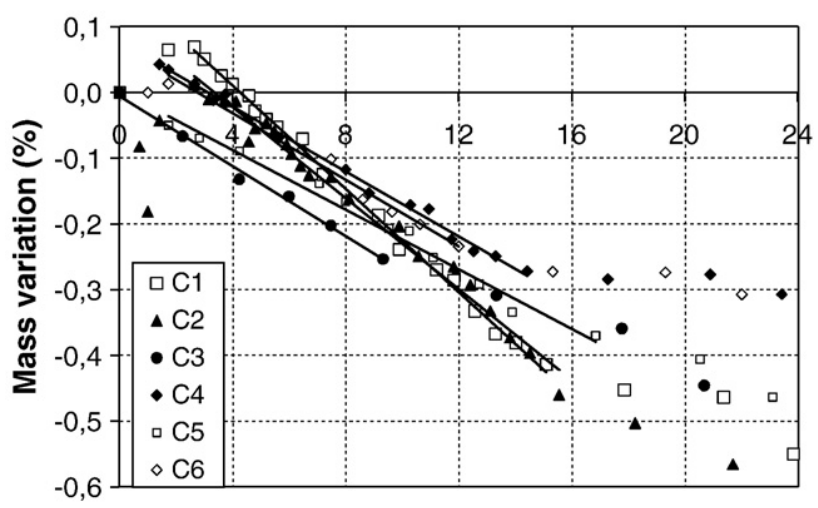

Square root of time (days ${ }^{1 / 2}$ )

Fig. 19. Difference of mass variations of immersed concrete specimens. [ $\left.\mathrm{SO}_{4}^{2-}\right]=3 \mathrm{~g} / \mathrm{L}$. Reference: mass before immersion.

gypsum and ettringite, the tests on concrete were designed to take into account sulphate concentration and control of the $\mathrm{pH}$ of the solution.

\subsubsection{External sulphate attacks in concrete}

The mass of control and attacked specimens was monitored. Control specimens stored in tap water showed a slight mass increase, which corresponds to hydration, whereas specimens stored in sulphate solution showed much lower increase or slight loss of mass. In order to separate the effect of sulphate attack from phenomena of absorption and hydration, differences of relative mass variations are plotted against square root of time in Fig. 19. The graph shows linear variations, which can be due to diffusion-reaction phenomenon, such as leaching and ingress of sulphate ions [6].

In order to compare these variations to the kinetics assessed from the leaching test, the kinetics from Fig. 19 were converted into loss of portlandite per unit area of sample (Table 9). They are of the same order of magnitude and they show the influence of composition parameters such as water/binder ratio and chemical composition of the binder. Significant differences appear for concrete mixtures C2, C3, and $\mathrm{C} 5$. The corresponding binders are mainly made of Portland cement.

Damaged depths can not be deduced only from leaching kinetics. As the sulphate test is still in progress, it is not possible to use a colorimetric indicator on a fracture of specimens. Visual observation can bring useful information on the degree of degradation, in a comparative approach [14]. Classification is given in Table 10 and shows good correlation with the classification from leaching test (Table 6).

The cement used in concrete mixtures C1B and C5B (see Fig. 21) is the high- $C_{3} A$ cement used in mortars M3, M9, and M12 but concrete mixtures are the same as $\mathrm{C} 1$ and $\mathrm{C} 5$. After immersion, expansion is due to absorption of water and depends on the magnitude of drying shrinkage before test. After this first stage, neither monitoring of mass nor monitoring of length shows expansion due to sulphate attack at both sulphate concentrations (Figs. 20 and 21). Even if controlled pH accelerates degradation [40], the sulphate attack is external and an

Table 9

Kinetics of loss of mass, from sulphate attack test and leaching test.

\begin{tabular}{lllll}
\hline & \multicolumn{2}{l}{ Sodium sulphate solution, $\left[\mathrm{SO}_{4}^{2-}\right]=3 \mathrm{~g} / \mathrm{L}, \mathrm{pH}=7$} & & Nitric acid solution, $\mathrm{pH}=5$ \\
\cline { 2 - 3 } & $k\left(\right.$ mass \%/day $\left.{ }^{1 / 2}\right)$ & $a_{\mathrm{Ca}(\mathrm{OH}) 2}\left(\mathrm{mmol} / \mathrm{dm}^{2} / \mathrm{day}^{1 / 2}\right)$ & & $a_{\mathrm{Ca}(\mathrm{OH}) 2}\left(\mathrm{mmol} / \mathrm{dm}^{2} / \mathrm{day}^{1 / 2}\right)$ \\
\hline $\mathrm{C} 1$ & 0.039 & 2.01 & - \\
$\mathrm{C} 2$ & 0.035 & 1.83 & 3.81 \\
$\mathrm{C} 3$ & 0.027 & 1.41 & 2.90 \\
$\mathrm{C} 4$ & 0.025 & 1.33 & 1.59 \\
$\mathrm{C} 5$ & 0.023 & 1.22 & 3.27 \\
$\mathrm{C} 6$ & 0.025 & 1.32 & 1.36 \\
\hline
\end{tabular}


Table 10

Classification of performances from external sulphate attack test on concrete.

\begin{tabular}{llll}
\hline & Time of immersion & Surface appearance & Classification of performances \\
\hline C1 & 597 & Porous - severe attack & 5 \\
C2 & 609 & Porous - severe attack & 5 \\
C3 & 463 & Slight attack & 3 \\
C4 & 578 & Very slight attack & 1 \\
C5 & 560 & Moderate attack & 4 \\
C6 & 519 & Very slight attack & 1 \\
\hline
\end{tabular}

increase in volume/surface ratio of specimens causes a corresponding increase in initiation time of degradation of paste [6], mortar (Fig. 4) and concrete specimens $[41,42]$. The test is actually not meant to classify performances of concrete mixtures by accelerated degradation, but to provide data on behaviour of concrete exposed to sulphate attack in realistic and controlled conditions. So these data can be useful to conclude on relevance of accelerated tests or models of external sulphate attacks [43] based on the evolution of the microstructure of concrete [44].

\section{Conclusions}

The aim of the study was to provide comparative performancebased tests and indicators to assess durability of concrete exposed to leaching and external sulphate attacks. Sensitivities of existing tests have been investigated and a new test has been developed for external sulphate attacks on concrete.

- Leaching test on concrete has shown good sensitivity: varying water/binder ratio and chemical composition of binder lead to significant changes in the behaviour of concrete. Three indicators can be assessed from test data, namely: total leached calcium at the end of the test, experimental damaged depth and equivalent damaged depth (for siliceous aggregates). This test is under evaluation for standardization.

- Test on mortar could be used to qualify binders, for a given water/ binder ratio and volume of paste. Conditions of exposure are not totally controlled and high sulphate concentration could be responsible for decreasing potential durability of sulphate-resisting Portland cements because of gypsum formation. The test is sensitive enough to show different behaviours of the studied reference binders, namely: high- $C_{3} A$ Portland cement, low- $C_{3} A$ sulphateresisting Portland cement, and sulphate-resisting slag cement. Experimental asymptotic analysis developed by Monteiro and Kurtis [39] from long-term study on concrete has been shown to be reliable to analyse data from the test.

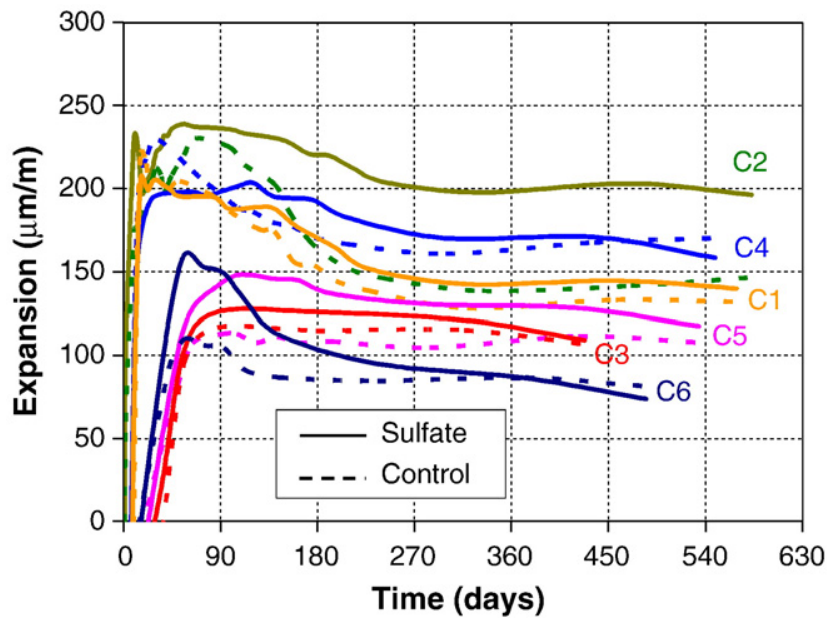

Fig. 20. Expansion of immersed concrete specimens. $\left[\mathrm{SO}_{4}^{2-}\right]=3 \mathrm{~g} / \mathrm{L}$.

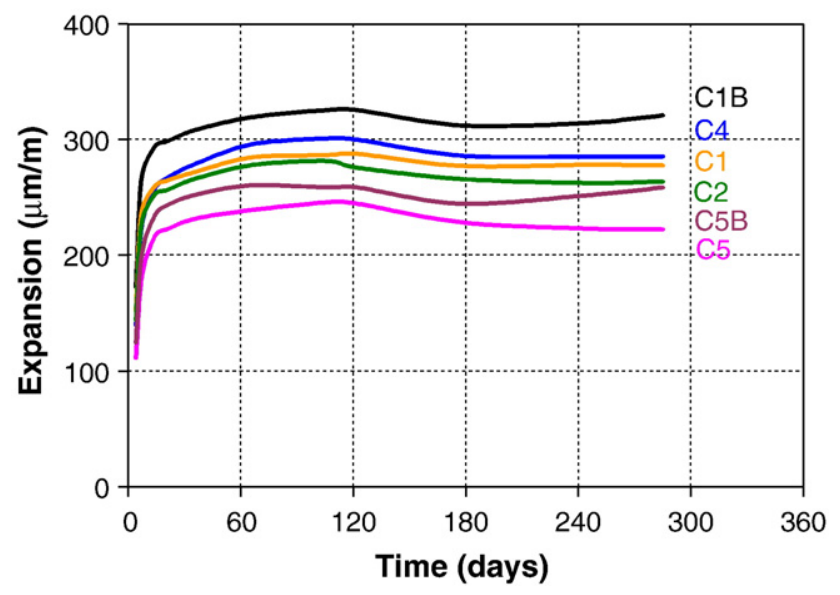

Fig. 21. Expansion of immersed concrete specimens. $\left[\mathrm{SO}_{4}^{2-}\right]=30 \mathrm{~g} / \mathrm{L}$.

- A new test has been developed to expose concrete to external sulphate attack in controlled conditions: $\mathrm{pH}$ is automatically controlled and two tests are still in progress at two sulphate concentrations ( $3 \mathrm{~g} / \mathrm{L}$ and $30 \mathrm{~g} / \mathrm{L} \mathrm{SO}_{4}^{2-}$ ). The long-term objective is to provide data to study relevance of the accelerated tests and models which are being developed.

- As classifications of performances are consistent, studies of external sulphate attack on mortars and concrete have both shown that leaching plays a predominant role. Leached portlandite would facilitate ingress of sulphate ions and produce reactants to form expansive products such as gypsum and ettringite. Portlandite comes from hydration of $C_{3} S$ and $C_{2} S$. So substitution of high- $C_{3} S$ Portland cement by $30 \%$ of fly ash improved behaviour of mortar or concrete exposed to leaching and sulphate attack. The best behaviour was obtained when Portland cement was substituted by $62 \%$ of ground granulated blast-furnace slag, either by using commercial slag cement or by blending Portland cement and slag in concrete.

\section{Acknowledgement}

The Fédération Nationale des Travaux Publics (from the French building industry) is gratefully acknowledged for its funding of the project.

\section{References}

[1] C. Carde, R. François, Modelling the loss of strength and porosity increase due to the leaching of cement pastes, Cem. Concr. Compos. 21 (1999) 181-188.

[2] M. Mainguy, C. Tognazzi, J.-M. Torrenti, F. Adenot, Modelling of leaching in pure cement paste and mortar, Cem. Concr. Res. 30 (2000) 83-90.

[3] F. Adenot, M. Buil, Modelling of the corrosion of the cement paste by deionized water, Cem. Concr. Res. 22 (1992) 259-272.

[4] S. Kamali, B. Gérard, M. Moranville, Modelling the leaching kinetics of cementbased materials - influence of materials and environment, Cem. Concr. Compos. 25 (2003) 451-458.

[5] M. Moranville, S. Kamali, E. Guillon, Physicochemical equilibria of cement-based materials in aggressive environments - experiment and modeling, Cem. Concr. Res. 34 (2004) 1569-1578.

[6] D. Planel, J. Sercombe, P. Le Bescop, F. Adenot, J.-M. Torrenti, Long-term performance of cement paste during combined calcium leaching-sulphate attack: kinetics and size effect, Cem. Concr. Res. 36 (2006) 137-143.

[7] N.J. Crammond, The thaumasite form of sulphate attack, Proceedings of the First Int. Conf. on Thaumasite in Cementitious Materials, BRE, 2002.

[8] K. Lipus, S. Punkte, Sulfatwiderstand unterschiedlich zusammengesetzter Betone, Tl.1 - Sulphate Resistance of Concretes with Different Compositions (Part 1), Beton - Dusseldorf, vol. 53, 2003, pp. 97-101, Part 2.

[9] R. Duval, H. Hornain, Chapitre 9: La durabilité du béton vis-à-vis des eaux agressives, dans La durabilité des bétons, sous la direction de J. Baron et J.-P. Ollivier, Presses de l'ENPC, 1992.

[10] A. Neville, The confused world of sulphate attack on concrete, Review, Cem. Concr. Res. 34 (2004) 1275-1296. 
[11] M. Santhanam, M.D. Cohen, J. Olek, Sulphate attack research - whither now? Cem. Concr. Res. 31 (2001) 845-851.

[12] D.D. Higgins, N.J. Crammond, Resistance of Concrete Containing ggbs to the Thaumasite Form of Sulphate Attack, paper presented at The First International Conference on Thaumasite in Cementitious Materials, Watford, UK, June 2002.

[13] H.A.F. Dehwah, Effect of sulphate concentration and associated cation type on concrete deterioration and morphological changes in cement hydrates, Constr. Build. Mater. 21 (2007) 29-39.

[14] E.F. Irassar, V.L. Bonavetti, M. Gonzalez, Microstructural study of sulphate attack on ordinary and limestone Portland cements at ambient temperature, Cem. Concr. Res. 33 (2003) 31-41.

[15] R. Tixier, B. Mobasher, Modeling of damage in cement-based materials subjected to external sulphate attack. I: formulation, J. Mater. Civ. Eng. 15 (4) (2003) 305-313.

[16] Y. Maltais, E. Samson, J. Marchand, Predicting the durability of Portland cement systems in agressive environments - laboratory validation, Cem. Concr. Res. 34 (2004) 1579-1589.

[17] NF EN 206-1 Béton - Partie 1: Spécification, performances, production et conformité, AFNOR, French standard, from European standard EN 206 Concrete Performance, production and conformity, 2004

[18] NF P 15-319 Liants hydrauliques - Ciments pour travaux en eaux à hautes teneurs en sulphates, Recueil de normes françaises, Béton et constituants du béton, Tome 3, 4ème édition, AFNOR, French standard, 1995.

[19] ASTM C 150 - 04a Standard Specification for Portland Cement, ASTM, 2002

[20] E. Rozière, A. Loukili, F. Cussigh, A performance based approach for durability of concrete exposed to carbonation, Constr. Build. Mater. 23 (2009) 190-199.

[21] ASTM C 1012 - 95a Standard Test Method for Length Change of HydraulicCement Mortars Exposed to a Sulphate Solution, Annual Book of ASTM Standards, volume 04.01 Cement; Lime; Gypsum, 2000.

[22] NF P 18-837 Produits de calage et/ou scellement à base de liants hydrauliques, Essai de tenue à l'eau de mer et/ou à l'eau à haute teneur en sulphates, AFNOR, French standard, 1993.

[23] W. Wittekindt, Sulfatbeständige Zemente und ihre Prufung, Zement-Kalk-Gips 13, H.2, 1960 , pp. $565-572$.

[24] L. Bucea, R. Khatri, V. Sirivivatnanon, Chemical and physical attack of salts on concrete, UrbanSalt 2005 Conference, 2005, 8-9 February.

[25] P.K. Mehta, Evaluation of sulphate-resisting cements by a new test method, ACI J. 72-40 (1975) 573-575.

[26] P.W. Brown, An evaluation of sulphate resistance of cements in a controlled environment, Cem. Concr. Res. 11 (1981) 719-727.

[27] M. Sahmaran, O. Kasap, K. Duru, I.O. Yaman, Effects of mix composition and watercement ratio on the sulphate resistance of blended cements, Cem. Concr. Compos. 29 (2007) 159-167.

[28] B. Bourdette, Durabilité du mortier: prise en compte des auréoles de transition dans la caractérisation et la modélisation des processus physiques et chimiques d'altération, Ph.D. thesis, INSA Toulouse, France, 1994.
[29] C. Badoz, P. Francisco, P. Rougeau, A performance test to estimate durability of concrete products exposed to chemical attacks, Proceedings of the Second International Congress of FIB, 2006, June 5-8.

[30] E. Spinner, W.E. Teft, A method for determining mechanical resonance frequencies and for calculating elastic modulus from these frequencies, in: Proceedings ASTM, ASTM, 1961, pp. 1221-1238.

[31] E. Rozière, Etude de la durabilité des bétons par une approche performantielle, $\mathrm{Ph}$ D. thesis, Ecole Centrale de Nantes, France, 2007.

[32] S.T. Lee, H.Y. Moon, R.N. Swamy, Sulfate attack and role of silica fume in resisting strength loss, Cem. Concr. Compos. 27 (2005) 65-76.

[33] B. Tian, M.D. Cohen, Does gypsum formation during sulphate attack on concrete lead to expansion? Cem. Concr. Res. 30 (2000) 117-123.

[34] R.P. Khatri, V. Sirivivatnanon, J.L. Yang, Role of permeability in sulphate attack, Cem. Concr. Res. 27 (8) (1997) 1179-1189.

[35] M.D.A. Thomas, M.H. Shehata, S.G. Shashiprakash, D.S. Hopkins, K. Cail, Use of ternary cementitious systems constaining silica fume and fly ash in concrete, Cem. Concr. Res. 29 (1999) 1207-1214.

[36] G.J. Osborne, Durability of Portland blast-furnace slag cement concrete, Cem. Concr. Compos. 21 (1999) 11-21.

[37] D.D. Higgins, Increased sulphate resistance of ggbs concrete in the presence of carbonate, Cem. Concr. Compos. 25 (2003) 913-919.

[38] T. Patzias, The development of ASTM method C1012 with recommended acceptance limits for sulphate resistance of hydraulic cements, Cem. Concr. Aggreg. (13) (1991) 50-57.

[39] P.J.M. Monteiro, K.E. Kurtis, Experimental asymptotic analysis of expansion of concrete exposed to sulphate attack, ACI Mater. J. 105 (1) (2008).

[40] R. Tixier, B. Mobasher, Modeling of damage in cement-based materials subjected to external sulphate attack. II: comparison with experiments, J. Mater. Civ. Eng. 15 (4) (2003) 314-322.

[41] B. Lagerblad, Long-term test of concrete resistance against sulphate attack, in: J. Marchand, J.P. Skalny (Eds.), Materials Science of Concrete: Sulphate Attack Mechanisms, American Ceramic Society, Westerbrook, Ohio, 1999, pp. 325-336.

[42] R. Tixier, Microstructural development and sulphate attack modelling in blended cement-based materials, PhD dissertation, Arizona State University, Tempe, 2000.

[43] E. Rozière, F. Grondin, A. Loukili, Modelling of the sulphate attack in cement-based materials, Proceedings of the International RILEM Symposium on Concrete Modelling CONMOD'08, Delft, The Netherlands, 26-28 May, 2008, pp. 199-206.

[44] F. Grondin, M. Bouasker, P. Mounanga, A. Khelidj, A multi-scales approach for the physico-chemical deformations of solidifying cement-based materials, Proceedings of the International RILEM Symposium on Concrete Modelling CONMOD'08, Delft, The Netherlands, 26-28 May, 2008, pp. 317-324.

[45] P. Lawrence, M. Cyr, E. Ringot, Mineral admixtures in mortars effect of type, amount and fineness of fine constituents on compressive strength, Cem. Concr. Res. 35 (6) (2005) 1092-1105. 